\title{
Volga YıImaz-Gümüş
}

Anadolu University

School of Foreign Languages, Turkey

\section{Translation of Culture-Specific Items in Self-Help Literature: A Study on Domestication and Foreignization Strategies'}

\author{
Summary
}

The last two decades have witnessed a boom in self-help materials in both global and local markets. This self-help trend, growing rapidly in our modern day, should be an area of interest for Translation Studies as an increasing number of self-help materials have been translated particularly from English every year. Self-help books involve a great deal of references to the material and social culture of the original country. One of the key issues in the translation of self-help books is the choice between foreignizing and domesticating these culture-specific items. This paper aims to discuss the procedures used for the translation of culture-specific items with regard to the particular function that these books assume in the target society. The analysis on the example of Outliers, a self-help book of sorts written by Malcolm Gladwell, has shown that the translator mostly adopted foreignizing strategies in translating the text into Turkish. The study also discusses whether these foreignizing strategies contribute to the fulfillment of target-text function, which is to provide quick-fix remedies to people struggling with modern-day challenges and demands.

Key words: Self-help literature, culture-specific items, foreignizing, domesticating

\section{Prevajanje kulturno specifičnih prvin v literaturi za samopomoč: razprava o strategijah podomačitve in potujitve}

\section{Povzetek}

V zadnjih dveh desetletjih smo bili priča razmahu gradiva za samopomoč, tako na globalnih kot na lokalnih trgih. Takšen trend bi moral biti posebej zanimiv za prevodoslovje, kajti vse več pripomočkov za samopomoč se prevaja zlasti iz angleščine. Knjige za samopomoč vsebujejo znatno količino referenc na materialno in družbeno kulturo izvorne dežele. Eno od osrednjih vprašanj pri prevajanju knjig za samopomoč je odločitev za podomačitev ali potujitev takšnih kulturno specifičnih prvin. Članek se osredinja na postopke pri prevajanju kulturno specifičnih prvin z ozirom na posebne vloge teh knjig v ciljni družbi. Analiza primera iz knjige za samopomoč z naslovom Outliers, ki jo je napisal Malcolm Gladwell, pokaže, da je prevajalec $v$ turščino zvečine prevzel strategije potujitve. Razprava poleg tega izpostavi problem učinkovitosti potujitvenih strategij za doseganje osnovnega namena takšnih besedil v ciljnem kontekstu, ki je v zagotavljanju hitre pomoči ljudem, obremenjenih s sodobnimi izzivi in zahtevami.

Ključne besede: literatura za samopomoč, kulturno specifične prvine, potujitev, podomačitev 


\section{Translation of Culture-Specific Items in Self-Help Literature: A Study on Domestication and Foreignization Strategies}

\section{Preliminary Considerations}

The number of self-help materials has been increasing dramatically in both global and local markets. Although thousands of self-help materials mainly from the United States enter into many national markets through translation every year, translation of self-help literature remains an unexplored area in Translation Studies. This study focuses on the translation into Turkish of a single bestselling self-help book with specific emphasis on the transfer of culture-specific items. By their very nature, self-help books are culturally loaded texts, and involve a great deal of references to material, social and even religious culture. One of the key issues in the translation of self-help books is the choice between foreignizing and domesticating the culture-specific items. The aim of this study is to discuss the procedures used for the translation of culture-specific items with regard to the particular function that these books assume in the target society.

A descriptive study based on the comparative analysis of source and target texts from a specific perspective allows us to identify translational behaviors and to study any matches and mismatches between theory and practice, as explained below by Lambert and van Gorp. Lambert and van Gorp's paper On Describing Translations was originally written twenty-five years ago. In that paper, the authors criticize the bare comparison of the source and target texts without consideration of other factors, particularly the target system. Yet they argue that comparison is still a part of translation studies, which we believe is a valid argument after a quarter century.

[...] the different translation strategies evident in the text itself provide the most explicit information about the relations between the source and target systems, and about the translator's position in and between them. Furthermore, the translated text is an obvious document for the study of conflicts and parallels between translational theory and practice. The comparison of T1 and T2 is therefore a relevant part of translation studies - as long as it does not obscure the wider perspective. (Lambert and Van Gorp 2006, 42)

The research on the development of self-help movement in the United States reports a history of over two centuries, dating back to the Autobiography of Benjamin Franklin published in 1790 (Toor 2011). However, in Turkey, the self-help movement started only in the second half of the $20^{\text {th }}$ century. Nüvit Osmay, reputed to be the first self-help professional and the pioneer of the self-help movement in Turkey, took courses from Dale Carnegie (the famous American writer and developer of self-help courses, 1888-1955) in the early 1950s and brought this trend into the Turkish culture. Özdemir $(2010,68)$ notes that the interest in self-help literature started in the 1990s, and flourished after the national economic crisis in 2001 in Turkey.

The main theme of self-help books is almost always the pursuit of happiness and/or success, and they cover a wide range of topics from test anxiety to memory improvement, from healthy life to family relationships. As defined by Bergsma (2008, 343), all books that serve the aim of "coping with one's personal or emotional problems without professional help" are self-help books. Self- 
help literature is worth studying because both for its cultural and socio-economic importance (Mur Effing 2009, 126). The size of the national and international self-help market is reported to be growing at the global and local scale. Although there is not any market research concerning the share of self-help books, "spiritual" books, it is assumed, make for half of the publishing sector of Turkey, which is 500 million Turkish liras (approximately US \$295 million) in total (Özkartal 2007). Other data is from the US market, according to which self-help constitutes an industry of $\$ 8$ billion in a year (Salerno, 2006). The translation of self-help literature is worth studying because translations hold a considerable share in this large self-help market. Another study on which I am working now shows that 452 self-help books were published in Turkey from January to December 2011, including reprints of older publications. Of these 452 books, 354 (78.3\%) were published for the first time in 2011, and the remaining are reprints. The more relevant data is that 200 (44.25\%) of the books are translations from English (193), German (4) and French (3).

It is interesting that the books mostly emerging in the American society and reflecting the American way of life and problem solutions are translated into many other languages, and become bestsellers both in the original and target culture. For example, Stephen Covey's The 7 Habits of Highly Effective People (1989) sold more than 15 million copies worldwide and was translated into thirty-two languages; ${ }^{2}$ John Gray's blockbuster Men Are from Mars, Women Are from Venus (1992) sold over 50 million copies worldwide and was translated into 42 languages. ${ }^{3}$ These high sales figures in the international market assign a specific position to the translation of self-help literature from the perspective of not only the publishing sector but also Translation Studies.

\section{Culture-Specific Items in Translation}

As already mentioned, by their nature, self-help books abound with references to the culture in which they emerge, mainly the United States. In her book titled Self-Help Books: Why Americans Keep Reading Them, Dolby (2005) discusses the importance of self-help books in the American community and also the reflections of the American culture and worldview in self-help books: "[...] they are surely popular expressive productions, and as such they both convey and incorporate elements of an American worldview" (2). Americans produce thousands of self-help books each year, and distribute most of these to international markets through translation together with the elements of the American worldview. How are these elements defined from the perspective of Translation Studies? Terestyényi (2011) draws attention to the fact that the concepts or realia and culture-bound or culture-specific expressions are used interchangeably to refer to both the objects and the "words that signify concepts that are related to a specific culture" (13). Below are two definitions of culture-specific items. In the first definition, (Aixelá 1996, 61-5) sees these items as translation problems due to their nonexistence or different status in the target culture:

Those textually actualized items whose function and connotations in a source text involve a translation problem in their transference to a target text, whenever this problem is a product of the nonexistence of the referred item or of its different intertextual status in the cultural system of the readers of the target text. (58) 
González Davies and Scott-Tennent (2005) provide a more specific definition of cultural references:

Any kind of expression (textual, verbal, non-verbal or audiovisual) denoting any material, ecological, social, religious, linguistic or emotional manifestation that can be attributed to a particular community (geographic, socio-economic, professional, linguistic, religious, bilingual, etc.) and would be admitted as a trait of that community by those who consider themselves to be members of it. Such an expression may, on occasions, create a comprehension or a translation problem. (166)

The common point in both definitions is that culture-specific items may constitute translation problems. A translator is required to adopt certain translation strategies to solve these problems. There have been various studies that attempt to define these strategies (see for example Newmark 1988; Hervey, Higgins and Haywood 1995; Vinay and Darbelnet 1995; Molina and Hurtado Albir 2002). For the purpose of this study, we refer to Aixelăs (1996) elaborate list of translation procedures for the "manipulation" of culture-specific items in translation. The translation procedures in his list fall under the tendency to either conserve or substitute culture-specific items in translation, which corresponds to the dichotomy of source- versus target-text orientation, or domestication versus foreignization in Translation Studies.

\begin{tabular}{|c|c|}
\hline Conservation procedures & Substitution procedures \\
\hline $\begin{array}{l}\text { repetition (keeping the original reference to the } \\
\text { extent possible) }\end{array}$ & $\begin{array}{l}\text { synonymy (not using the culture-specific item } \\
\text { and substituting it with "a parallel reference" in } \\
\text { the target text) }\end{array}$ \\
\hline $\begin{array}{l}\text { orthographic adaptation (in the form of } \\
\text { transcription or transliteration) }\end{array}$ & $\begin{array}{l}\text { limited universalization (using "another } \\
\text { reference, also belonging to the source language } \\
\text { culture but closer to their readers") }\end{array}$ \\
\hline $\begin{array}{l}\text { linguistic (non-cultural) translation (choosing "a } \\
\text { denotatively very close reference to the original”) }\end{array}$ & $\begin{array}{l}\text { absolute universalization (eliminating the } \\
\text { "foreign connotations" and replacing them with } \\
\text { "a neutral reference") }\end{array}$ \\
\hline $\begin{array}{l}\text { extratextual gloss (using footnote, endnote, } \\
\text { glossary, commentary/translation in brackets, in } \\
\text { italics, etc. to offer some extra explanation about } \\
\text { a culture-specific item) }\end{array}$ & naturalization (adaptation) \\
\hline \multirow[t]{2}{*}{$\begin{array}{l}\text { intratextual gloss (providing gloss within the text } \\
\text { in order not to distract the readers' attention) }\end{array}$} & $\begin{array}{l}\text { deletion (omitting the culture-specific item in } \\
\text { the target text for various reasons) }\end{array}$ \\
\hline & $\begin{array}{l}\text { autonomous creation (adding "some nonexistent } \\
\text { cultural reference in the source text") }\end{array}$ \\
\hline
\end{tabular}

Table 1. Procedures Used for the Translation of Culture-Specific Items (Aixelá 1996, 61-65)

\section{Translation of Culture-Specific Items in a Self-Help Book, Outliers}

\subsection{Target Readers and Skopos of the Translation}

Prior to making a comparative analysis of source and target texts, we need to identify target readers and skopos of translations into Turkish. The target audience of self-help books is usually 
the general public, seeking quick-fix solutions to their daily problems, concerns or tensions, and seeking a guide to keep up with increasing demands of modern life. To reach everyone who needs ready-made solutions, according to Mur Effing (2009), the self-help genre usually has the following style of writing:

From the very beginnings of the genre, and even more toward the second half of the twentieth century, self-help writers appear to take on the role of the psychologist, priest or counsellor. Although privileged in knowledge and wisdom, the authors often express themselves adopting a friendly, easy-to understand and 'reachable' tone as if one was talking to a friend who lets you in on a secret. Story writing was the method most self-help authors used, and still use, to communicate their messages best to a wide, mostly undereducated public. In fact, the style of teaching through stories is one of the characteristics of most self-help literature books throughout time. (133, emphasis added)

This explanation provides us clues also about the skopos of the translation of self-help books. The target audience expects easily understandable and easily applicable solutions from the author. To our knowledge, in the Turkish context, there is no study or survey regarding the target readers of self-help literature. Yet for target readers from either uneducated or well-educated public, the purpose of self-help literature is not to present academic or specialized knowledge in a specific field, or provide deeper insight into life problems or leave a literary taste in readers' minds. They serve the function of a sort of guide that offers effortless solutions that does not entail further research and thinking. Thus, this requires a "fluent translation" ${ }^{4}$ frequently purified of foreign and hence incomprehensible items that interrupt the understanding of readers.

\subsection{About Outliers: The Story of Success}

The book that is analyzed here with regard to the translation of culture-specific items is Outliers: The Story of Success by Malcolm Gladwell, published in 2008. Malcolm Gladwell is a writer and journalist, who was born in England, grew up in Canada and now lives in the US. He does not have formal education in psychology or psychiatry, which is not an uncommon case in self-help literature. He has other bestselling self-help books such as The Tipping Point: How Little Things Can Make a Big Difference, Blink: The Power of Thinking Without Thinking and What the Dog Saw. Outliers was translated into Turkish in 2009 by Aytül Özer and published by MediaCat Publishing, and has had 10 reprints since then. The Turkish publisher MediaCat is a publishing house that is particularly specialized in marketing communications and that has published over 200 books so far. $^{5}$

Outliers is divided into two parts as Opportunity and Legacy, each subdivided into chapters. The book has an introduction as a distinct part and an epilogue as one of the chapters in Part II, both telling stories. What distinguishes Outliers from other self-help books is that it does not promise achievement through solely individual efforts, but attempts to provide understanding about the concept of success, incorporating social, environmental, cultural or familial factors through true stories. Although Outliers is not one of the thousands of self-help books that provide three,

For the use of this term, see Venuti, 1995.

For more information see http://www.mediacatonline.com/Home/Kitap. 
thirty, or three hundred ways to achieve a goal, it is still a typical self-help book communicating messages on success with the use of storytelling technique, i.e. life stories of prominent figures mostly from the US and attention-grabbing events.

\subsection{Translation of the Title}

The title is of particular importance in self-help books as they are generally formulated conspicuously to capture the attention of readers at first sight with humorous, interrogative or didactic expressions. In the case of Outliers, the front covers of English and Turkish versions of the book appear as follows:

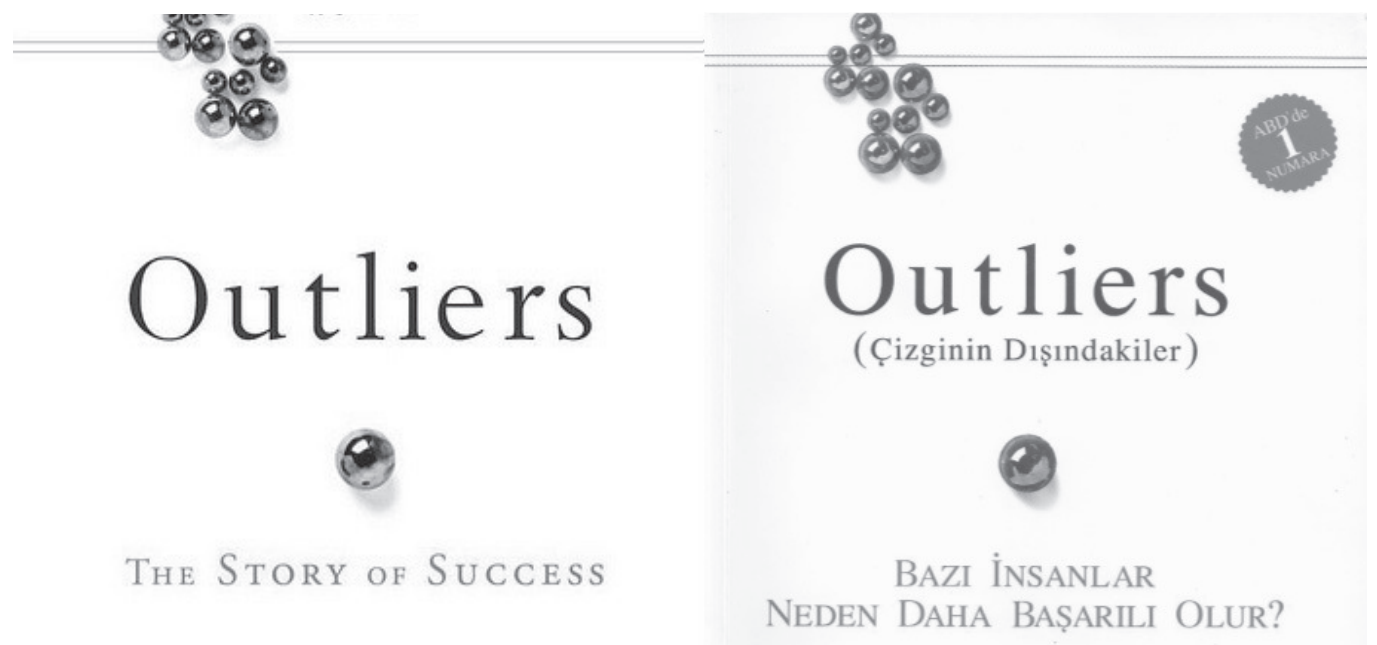

M A L C O L M

G L A D W E L L

M A L C O L M

GLA D W E L L

\#1 bestselling authos of The Tipping Point and Blink

MediaCat

Figure 1. Front covers of the original book and the Turkish translation

The main title is conserved without translation in the Turkish version of the book. This corresponds to the repetition procedure in Aixeläs list. The Turkish explanation of "outliers" is additionally provided in parentheses, which translates into English as "those who are out of the line". Finally, the subtitle "The Story of Success" is translated in question form, literally meaning "Why do Some People Become More Successful?" The conservation of the title in its original form is not a very common procedure in translations into Turkish; however, it has been a recent proclivity in the translation of titles of self-help books to combine the original one with a Turkish title. For instance, Rhonda Byrne's The Secret and The Power appeared in Turkish and all other languages with their original titles and front covers combined with the target-language equivalent of the original title. Following the same tendency, the Turkish translation of Outliers presents the original title together with the Turkish translation (or explanation) of the original. A more recent book by the same author is also published with the English title and its Turkish translation: What the Dog Saw (Köpeğin Gördü̈̆̈̈). 
This tendency to preserve the original title finds explanation in the polysystem theory. A history of the self-help literature in Turkey shows that translated self-help literature occupies a central position not in the publishing polysystem but in the self-help publishing system of Turkey. In Even-Zohar's (1990) words,

Since translational activity participates, when it assumes a central position, in the process of creating new, primary models, the translator's main concern here is not just to look for ready-made models in his home repertoire into which the source texts would be transferable. Instead, he is prepared in such cases to violate the home conventions. (50)

In the example of title translation, we can see that the translation breaks the conventions in the target culture. The translation of Rhonda Byrne's The Secret probably introduced this new rule into the target system, which is followed by other translations as well. In the case of The Secret or The Power, it is probably not the translator's decision but an agreement with the original publisher to preserve the title in translated versions of the books in that all language versions of these books have the same title and front cover. Time will tell whether this new convention is accepted or rejected by target audiences.

\subsection{Translation of Culture-Specific Items}

Jull Costa $(2007,118)$ claims that cultural, historical and geographical references are easier to translate compared to linguistic and cultural concepts that may not have an equivalent in the target language because they do not require interpretation. However, as she also notes, it is important how much and how to explain these references in consideration of the target reader and skopos of the text.

The book we chose for this study provides a great many of historical, geographical and cultural references that are probably familiar to many American readers, but not to Turkish readers. Lots of proper names (e.g. specific districts, universities or companies), personal names or historical events are probably familiar to an American reader, but have little or no bearing for the target audience. The next part of the study provides examples of cultural references in Outliers and attempts to explain how they were translated into Turkish.

\subsubsection{Translation of personal names and locational references}

Example 1:

ST (Source Text) - Louis and Regina found a tiny apartment on Eldridge Street, on Manhattan's Lower East Side, for $\$ 8$ a month. (161)

TT (Target Text) - Louis ve Regina Manhattan'ın așağı doğu yakasındaki Eldridge Caddesi'nde ayda 8 dolara minik bir daire buldular. (106)

BT (Backtranslation) - Louis and Regina found a tiny apartment on Eldridge Street, on lower east side of Manhattan, for $\$ 8$ a month.

TS (Translation Strategy) - repetition, linguistic translation

Example 2:

ST - The distinctive buildings that still stand on the lower half of Broadway in Manhattan 
- from the big ten- and fifteen-story industrial warehouses in the twenty blocks ${ }^{6}$ below Times Square to the cast-iron lofts of SoHo and Tribeca - ... (167)

TT - Times Meydanı'nın 20 blok altındaki 10, 15 katlı endüstriyel depolardan $\underline{\text { SoHo ve }}$ Tribecánın demir döküm çatı katlarına, Manhattan'da Broadway' in alt kesiminde hala varlığını koruyan dikkat çekici binaların hemen hepsi... (109)

BT - the same

TS - repetition, linguistic translation

The above examples from the book are two of many locational (or geographical) references in the book. Although they may not have a descriptive sense even in the source language, they must have references in the minds of source readers. As argued by Nord (2003), "[i]n the real world, proper names may be non-descriptive, but they are obviously not non-informative" (183) if the reader is familiar with the given culture. Readers familiar with the source culture would have an idea about Manhattan or Elridge Street as well as many other locational references in the books such as SoHo, Tribeca, Times Square or Broadway, and what sort of people live in these places or what sort of shops there are in these areas. However, if the referents of these names are completely unfamiliar to the reader, they are not expected to have connotations in the minds of target readers. The place names are apparently preserved (repeated) or descriptors accompanying them, e.g. street and square, are translated into Turkish.

Similarly, the following names are cited in the text as figures of success; however, we are not sure whether these names, except for Steve Jobs, create an image of success in the minds of Turkish readers: Paul Allen, Steve Ballmer, Steve Jobs, Eric Schmidt or Bill Joy (73-6). The translator clearly has no other choice than to repeat the above-mentioned proper or place names. The basic problem with such proper names is not directly related with translation processes, but with preliminary norms in translation including translation policies that govern text selection processes. There is a need for studies or reader surveys in order first to identify the expectations of target readers from these texts more clearly and then to find out whether the translated texts (texts chosen and translation strategies employed) fulfill these expectations in the target culture.

\subsubsection{Translation of historical and political references}

Example 3:

ST - Flom grew up in the Depression in Brooklyn's Borough Park neighborhood. (133) TT - Flom Büyük Buhran döneminde Brooklyn'in Borough Park çevresinde büyüdü. (89) BT - Flom grew up in the Great Depression era in Brooklyn's Borough Park neighborhood.

TS - linguistic translation (non-cultural), intratextual gloss (limited)

The translation of this historical reference provides an example of linguistic translation combined with an intratextual gloss. The translator adds the "era" to show that the Depression is a temporal concept, and glosses the concept as the "Great Depression" as it is referred to in the Turkish culture.

This example also provides a language use from daily life. "Block" is used here for the purpose of address description. This is a concept that is not used in the Turkish context for the same purpose, but was translated non-culturally into Turkish. 
Example 4:

ST - If you were born in the 1820s you were too old: your mind-set was shaped by the pre-Civil War paradigm. (70)

TT - 1820’lerin sonlarında doğmuş olmanız durumunda ise fazla yaşlıydınız; düşünce biçiminiz Sivil Savas öncesi paradigmayla biçimlenmiş durumdaydı. (48)

BT - If you were born in the 1820s you were too old: your mind-set was shaped by the pre-Civil War paradigm.

TS - linguistic translation

In this example, the translator does a word-for-word translation of the concept "Civil War", and intentionally or unintentionally does not use the expression "İç Savaş" (literally the Internal War), which is the equivalent of civil war in the Turkish language.

Example 5:

ST - One summer the family lived on an Indian reservation in a tepee, subsisting on government-surplus peanut butter and cornmeal. For a time, they lived in Virginia City, Nevada. "There was only one law officer in town, and when the Hell's Angels came to town, he would crouch down in the back of his office," Mark Langan remembers. (104) TT - Bir yaz aile Kızılderililere ayrılan arazilerden birinde bir Kızılderili çadırında yaşadı, devletin verdiği stok fazlası fistık ezmesi ve mısırla karnını doyurdu. Bir süre Nevada’da Virginia City'de yaşadılar. "Kasabada sadece tek bir hukuk görevlisi vardı ve Cehennem Melekleri kasabaya geldiğinde o da ofisinin arka tarafında yere çömelip saklanırd»" diye aktarıyor anımsadıklarını Mark Langan. (71-2)

BT - One summer the family lived on one of the lands reserved to the Indians in an Indian tent subsisting on government-surplus peanut butter and corn. For a time, they lived in Virginia City in Nevada. "There was only one law officer in town, and when the Hell's Angels came to the town, he would crouch down in the back of his office."

TS - intratextual gloss, linguistic translation

In this segment from the text, "Indian reservation", a politically loaded term from the American system, is explained inside the text (intratextual gloss). In the same sentence, the term "tepee" is explained with an intratextual gloss as the Indian tent. "Hell's Angels", a motorcycle gang that emerged during the World War II, is linguistically translated into Turkish without any further explanation, probably with no bearing for the target reader.

\subsubsection{Translation of references from social and daily life}

Example 6:

ST - Armed with a large grant from the Commonwealth Foundation, he put together a team of fieldworkers ... (83)

TT - Commonwealth Foundation adlı vakıftan aldığı büyük miktarda bağışla, bir saha çalışanları ekibi kurarak... (56)

BT - With a large grant he received from a foundation called the Commonwealth Foundation, he put together a team of fieldworkers ...

TS - repetition, limited intratextual gloss 
The Commonwealth Foundation, a research and educational institute, is also repeated in the target text without any change and is followed by the limited intratextual gloss that it is a foundation.

Example 7:

ST - The television show $\underline{I \text { vs. } I 00}$ is one of many that sprang up in the wake of the phenomenal success of Who Wants to Be a Millionaire. (77)

TT - I vs. I00, Who Wants to Be a Millionaire' in* gösterdiği olağanüstü başarının ardından ortaya çıkan birçok televizyon programından biri. (53)

* Ç.N. Türkiye'de Kim Beş Yüz Milyon İster? olarak uyarlanmıştır.

$\mathrm{BT}-\underline{I \text { vs. } I 00}$ is one of many television programs that sprang up in the wake of the phenomenal success of Who Wants to Be a Millionaire.

* Translator's Note: It was adapted in Turkey as Who Wants Five Hundred Millions.

TS - repetition, extratextual gloss (footnote), deletion

In this excerpt, the TV shows I vs. 100 and Who Wants to be a Millionaire are kept in their original form. This is the only part in the translated book where the translator adds a footnote. Who Wants to be a Millionaire was adapted into Turkish. Rather than using the Turkish name of the TV show, the translator keeps the American name in the text and adds a footnote to mention the Turkish name. However, the Turkish adaptation was first named as Who Wants Five Hundred Billions, and now the current name is Who Wants to Be a Millionaire, after removing six zeros from the Turkish currency. In the footnote, the translator provides incorrect information.

Example 8:

ST - You need to be at least six foot or six one to play at that level, and, all things being equal, it's probably better to be six two than six one, and better to be six three than six two. (90)

TT - O düzeyde basketbol oynamak için boyunuzun en az 1,83 ya da 1,86 olması gerekiyor ve eşit koşullarda $\underline{1,89}$ 'luk bir boy $1,86^{\prime} \mathrm{l} \mathrm{k}$ bir boydan ya da $1,92^{\prime}$ lik bir boy 1,89 'luk bir boydan daha iyi olsa gerek. (61)

BT - To play basketball at that level, you should be at least 1,83 or 1,86 , and under equal circumstances, it must be better to have a height of 1,89 rather than 1,86 , and to have a height of 1,92 rather than 1,86 .

TS - naturalization (adaptation)

This is one of the few examples where the translator used adaptation. In this excerpt, the height of basketball players given in foot is converted into $\mathrm{cm}$, i.e. the metric system used in Turkey. Translation and conversion are used together.

\subsubsection{Translation of references from educational system}

Example 9:

ST - When it came time to apply to college, Joy got a perfect score on the math portion of the Scholastic Aptitude Test. (47)

TT - Üniversiteye başvurma zamanı geldiğinde, Joy, Scholastic Aptitude Test adlı yetenek testinin matematik bölümünden mükemmel bir puan aldı. (36) 
BT - When it came time to apply to college, Joy got a perfect score on the math portion of the aptitude test called the Scholastic Aptitude Test ...

TS - repetition, intratextual gloss (limited)

The Scholastic Aptitude Test, a standardized test designed to measure certain skills of students, is required for college admission in the American education system. In this example, this cultural term is repeated (in other words, conserved) in the target text. The limited intratextual gloss within the text solely explains that the SAT is an aptitude test.

Example 10:

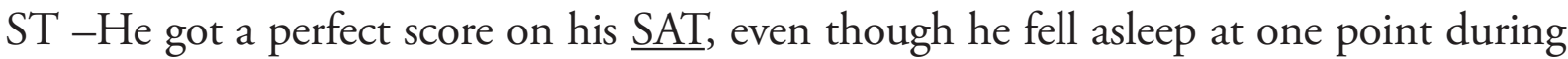
the test. (80)

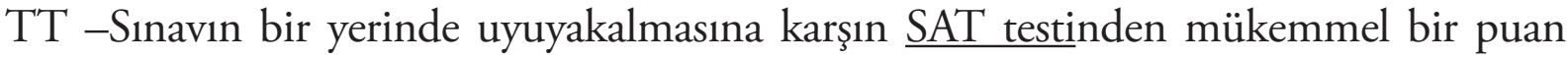
aldi. (55)

BT - Even though he fell asleep at one point during the test, he got a perfect score on his SAT test.

TS - repetition, intratextual gloss

In another example, the author uses the abbreviation for the Scholastic Aptitude Test. The procedure preferred by the translator is almost the same, i.e. repetition followed by limited information. The limited information only elucidates that the SAT is a test.

Example 11:

ST - Most colleges didn't have computer clubs in the 1960s. (57)

TT - 1960’larda çoğu üniversitenin bile bilgisayar kulübü yoktu. (42)

BT - Even most colleges didn't have computer clubs in the 1960s.

TS - naturalization

Another example from school life is concerning the use of "college". Whereas college refers to a higher education institution in the United States, the Turkish transcription "kolej" is used for some specific secondary schools, e.g. a police college or a private college. This constitutes another example of adaptation strategy used in translation.

Example 12:

ST - To get a sense of how absurd the selection process at elite Ivy League schools has become, consider the following statistics. (94)

TT - ABD'nin (binalarının sarmaşık kaplı olması nedeniyle Ivy League denilen) sekiz saygın geleneksel üniversitesinde (Brown, Columbia, Cornell, Dartmouth College, Harvard, Princeton, Pennsylvania ve Yale) öğrenci seçme sürecinin ne kadar absürd hale geldiği konusunda fikir sahibi olmak için aşağıdaki istatistikleri göz önüne alın. (64)

BT - To get a sense of how absurd the student selection process at eight elite traditional universities of America (Brown, Columbia, Cornell, Dartmouth College, Harvard, Princeton, Pennsylvania and Yale) (known as Ivy League because their walls are covered with ivies), consider the following statistics.

TS - repetition, extratextual gloss, intratextual gloss 
In the above example, even the length of source and target texts provides clues about the translation. The translator employs three different conservation procedures, 1) keeping the Ivy League (repetition), 2) providing intratextual gloss, saying that these are eight old universities of the US, and also 3) giving extratextual gloss in parentheses, explaining why they are called the Ivy League and providing the names of the universities. Although Aixelá defines all these procedures as conservation, these comprehensive extratextual and intratextual glosses are added to eliminate the alienation posed by the term Ivy League in the source text.

\section{Conclusion}

Self-help books, mostly involving stories from real life, may involve as many cultural references as in literary works. However, the target readers of self-help literature and their expectations are probably different from those of literature as self-help books serve a completely different function. In literary translation, if the skopos does not something else, there is tendency to use source-text oriented techniques in translation in order to assure the representation of a source culture in the target culture, as defended by Venuti (1995). However, with regard to self-help books, the skopos and target audience require easily understandable contexts that do not force the reader to carry out further research. The readers of these books and their translations usually seek ready-made and quick-fix solutions to their problems probably in the midst of their hectic life. They are not supposed to have time to check any source-culture reference in the target text, or do not prefer these books in order to enhance their intellectual or cultural knowledge. That is why, before the analysis, we assumed that the translator may have opted for domesticating or substitutive procedures for the translation of cultural references, to the extent possible to provide readers with a more fluent reading. Our expectation was that the translator used more universalization, more naturalization, and even more deletion, in Aixelás terms. Nevertheless, above examples show that the translator usually preferred conservation procedures. We can see the frequent use of linguistic translation and intratextual and extratextual glosses. The translator used substitution procedures only in compulsory situations when the translation would be totally incomprehensible (see the "feet" example above) or confusing (see the "college" example) for the target reader. Before the analysis of culture-specific items, the title translation, i.e. the conservation of the original title in translation, has already shown that the translator was inclined to adopt foreignizing strategies in the translation process. The foreignizing procedures in translation probably interrupt a fluent reading of the target text and prevent the text from fulfilling its function of offering quick and easy solutions to readers.

Translation research on works on the periphery of the polysystem (e.g. self-help literature, travel writing, chick lit) is important for the publishing sector as most of these works enter the Turkish culture from foreign cultures and inspire the production of local works in the same genre. Further, particularly the translations hold a considerable share in the market. These products sell very well and reach a great numbers of readers in the target culture. Translation-oriented research on these works may contribute to the improvement of the quality in the translation and original production of similar works, and encourage translators to gain deeper insight into their translation decisions. Furthermore, studies or surveys with readers may provide data for preliminary decisions with regard to the selection of texts to be translated (i.e. translation policies) and for the initial decision on whether to adopt source culture and target culture norms. 


\section{Bibliography}

Aixelá, J.F. 1996. Culture-specific Items in Translation. In Translation, Power, Subversion, eds. R. Álvarez and M.C. África Vidal, 52-78. Clevedon: Multilingual Matters.

Bergsma, A. 2008. Do Self-Help Books Help? Journal of Happiness Studies 9: 341-60.

Dolby, S.K. 2005. Self-Help Books: Why Americans Keep Reading Them. Urbana, Illinois: University of Illinois Press.

Even-Zohar, I. 1990. The Position of Translated Literature within the Literary Polysystem. Poetics Today 1, no. 1: 45-52.

González Davies, M., and C. Scott-Tennent. 2005. A Problem-Solving and Student-Centered Approach to the Translation of Cultural References. Meta 50, no. 1: 160-79.

Hervey, S., I. Higgins, and L.M. Haywood. 1995. Thinking Spanish Translation: A Course in Translation Method: Spanish to English. London: Routledge, 1995.

Jull Costa, M. 2007. Mind the Gap: Translating the 'Untranslatable'. In Voices in Translation. Bridging Cultural Divides, ed. G. Anderman, 111-22. Clevedon: Multilingual Matters.

Lambert, J., and H. van Gorp. 2007. On Describing Translations. In Functionalist Approaches to Culture and Translation. Selected Papers by José Lambert, eds. D. Delabastita, L. D'hulst, and R. Meylaerts, 37-48. Amsterdam and Philadelphia: John Benjamins.

Molina, L., and A. Hurtado Albir. 2002. Translation Techniques Revisited: A Dynamic and Functionalist Approach. Meta 47, no. 4: $498-512$.

Mur Effing, M. 2009. The Origin and Development of Self-help Literature in the United States: The Concept of Success and Happiness, an Overview. Atlantis 31, no. 2: 125-41.

Newmark, P. 1988. Approaches to Translation. London: Prentice Hall.

Nord, C. 2003. Proper Names in Translations for Children. Alice in Wonderland as a Case in Point. Meta 48, nos. 1-2: 182-96.

Özdemir, I. 2010. Kişisel Gelişim Kitaplar n n Eleştirel Bir De erlendirmesi [A Critical Evaluation of Self-Help Books]. Ankyra 1, no. 2: 63-95.

Özkartal, M.Z. 2007. Neo-kadercinin Başucu Kitaplar [Reference Books for Neo-fatalists]. Milliyet Kitap (Turkey), May 15, 2007. Also available online at http://www.milliyet.com.tr/2007/05/15/kitap/akit.html (accessed February 1, 2012)

Salerno, S. 2006. SHAM: How the Self-Help Movement Made America Helpless. New York: Three Rivers Press.

Terestyényi, E. 2011. Translating Culture-specific Items in Tourism Brochures. SKASE Journal of Translation and Interpretation 5, no. 2: 13-22. http://www.skase.sk/Volumes/JTI06/pdf_doc/02.pdf (accessed February 1, 2012)

Toor, R. 2011. Learning to Write from Uncle Ben. The Chronicle of Higher Education, January 18, 2011. http://chronicle.com/ article/Learning-to-Write-From-Uncle/125964/ (accessed January 21, 2012)

Venuti, L. 1995. The Translator's Invisibility: A History of Translation. London: Routledge.

Vinay, J.P., and J. Darbelnet. 1995. Comparative Stylistics of French and English. Amsterdam and Philadelphia: John Benjamins. 